\title{
PENENTUAN KELAS KUAT KAYU LOKAL DI PULAU TIMOR SEBAGAI BAHAN KONSTRUKSI
}

\author{
Koilal Alokabel ${ }^{1}$, Yermias E. Lay ${ }^{2}$, Teddy Wonlele ${ }^{3}$
}

\begin{abstract}
Abstrak :
Penggunaan kayu lokal sebagai bahan konstruksi di NTT umumnya dan Pulau Timor khususnya sering digunakan tidak hanya sebagai bangunan milik masyarakat tetapi juga pada bangunan negara atau proyek pemerintah. Jenis-jenis kayu lokal di Pulau Timor yang sering dipakai sebagai bahan konstruksi seperti Kayu Jambu Air, Kabesak, Johar, Mahoni, Ketapang Hutan, Jati Putih (Gamalina) dan beberapa jenis kayu lain yang banyak terdapat di Pulau Timor.

Permasalahan yang sering timbul adalah klaim mutu kayu lokal yang tidak mudah dibuktikan oleh kontraktor karena sebagian besar kayu lokal belum masuk dalam daftar jenis mutu kayu dalam Peraturan Konstruksi Kayu Indonesia 1961 atau SNI Kayu Tahun 2002. Hal ini menyebabkan ketidakpastian hukum kontrak antara pengguna jasa (pemerintah) dan penyedia jasa (kontraktor) karena umumnya untuk konstruksi syarat kelas kuat kayu dan mutu kayu wajib dicantumkan. Disatu sisi pengguna jasa menginginkan kayu sebagai bahan konstruksinya harus dari kayu kelas II misalnya sedangkan disisi yang lain penyedia jasa atau kontraktor menggunakan kayu lokal yang menurutnya termasuk kayu kelas II, karena ketersediaan kayu kelas II di pasaran sulit diperoleh.

Hasil penelitian menunjukan bahwa kuat tekan rata-rata kayu Gamalin adalah 30,39 Mpa, kayu Kabesak 34 Mpa, kayu Johar 62,18 Mpa, kayu Jambu Air 48,58 Mpa, kayu Ketapang Hutan 33, 07 Mpa, kayu Mahoni 30,49 Mpa. Kadar air kayu Gamalin adalah 18,30 \%, kayu Kabesak $17,73 \%$, kayu Johar 18,83 \%, kayu Jambu Air 19,90 \%, kayu Ketapang Hutan 18,85 \%, kayu Mahoni 18,73 \%. Berat jenis kayu Gamalin adalah 0,54 kayu Kabesak 0,62, kayu Johar 0,85, kayu Jambu Air 0,67, kayu Ketapang Hutan 0,58, kayu Mahoni 0,54. Hasil ini menunjukkan bahwa kayu lokal Timor sangat kuat, mempunyai kadar air yang baik dan mempunyai berat jenis yang baik pula.
\end{abstract}

Kata kunci : Kayu lokal, Kelas kuat.

\section{PENDAHULUAN}

Kayu merupakan salah satu material konstruksi yang paling banyak terdapat di alam dan pertama kali digunakan dalam sejarah umat manusia. Kayu sampai saat ini masih banyak digunakan sebagai bahan konstruksi bangunan untuk rumah tinggal, gedung, jembatan, bantalan kereta api dan lain - lain. Kayu dipilih sebagai bahan konstruksi selain karena alasan mudah didapat, harganya relatif murah dan memiliki nilai estetika yang tinggi.

(Frick, 1981) juga menyatakan bahwa material kayu akan selalu dibutuhkan manusia karena sifat utama yang dimiliki yaitu kayu merupakan kekayaan alam ( natural resources ) yang tidak akan pernah habis, mudah dalam pemrosesan serta memiliki sifat-sifat spesifik yang tidak dimiliki oleh bahan lain. Selain 
keuntungan kayu seperti yang telah disebutkan di atas kayu juga mempunyai kekuatan yang tinggi ( tekan sejajar atau tegak lurus serat) dan berat yang rendah dibandingkan dengan konstruksi yang lainnya, mempunyai daya tahan yang tinggi terhadap pengaruh kimia (Chemical Attack), dan bersifat isolator. Namun demikian kayu juga memiliki kekurangan antara lain sifat kurang homogen dengan adanya cacat kayu, mata kayu, beberapa bersifat kurang awet, dapat memuai dan menyusut dengan perubahan kelembaban meski tetap elastis dan yang terutama adalah kayu mudah terbakar. Tidak semua jenis kayu dapat dijadikan bahan konstruksi. Penilaian terhadap kayu di bedakan atas kelas kuat dan kelas awetnya.

Penggunaan kayu lokal sebagai bahan konstruksi di NTT umumnya dan Pulau Timor khususnya sering digunakan tidak hanya sebagai bangunan milik masyarakat tetapi juga pada bangunan negara atau proyek pemerintah.

Jenis-jenis kayu lokal di Pulau Timor yang sering dipakai sebagai bahan konstruksi seperti Kayu Jambu Air, Nangka, Kayu Putih, Cemara (Kayu Kasuari), Mangga Hutan, Kayu Reo (Kedondong Hutan), Jati Putih (Gamalina), Ketapang dan beberapa jenis kayu lain yang banyak terdapat di Pulau Timor.

Permasalahan yang sering timbul adalah klaim mutu kayu lokal yang tidak mudah dibuktikan oleh kontraktor karena sebagian besar kayu lokal belum masuk dalam daftar jenis mutu kayu dalam Peraturan Konstruksi Kayu Indonesia 1961 atau SNI Kayu Tahun 2002. Hal ini menyebabkan ketidakpastian hukum kontrak antara pengguna jasa (pemerintah) dan penyedia jasa (kontraktor) karena umumnya untuk konstruksi syarat kelas kuat kayu dan mutu kayu wajib dicantumkan.

Disatu sisi pengguna jasa menginginkan kayu sebagai bahan konstruksinya harus dari kayu kelas II misalnya sedangkan disisi yang lain penyedia jasa atau kontraktor menggunakan kayu lokal yang menurutnya termasuk kayu kelas II, karena ketersediaan kayu kelas II di pasaran sulit diperoleh.
Kurangnya publikasi terhadap mutu kayu lokal ini juga menjadi sebab terjadinya perselisihan dalam pekerjaan konstruksi di NTT. Sebagian besar bahkan sudah sampai pada meja hijau karena banyaknya pandangan terhadap mutu kayu yang dipakai dalam proyek Pemerintah.

Berdasarkan kondisi inilah, Politeknik sebagai lembaga Pendidikan/Penelitian dan juga sering diminta pendapat dalam penanganan kasus tersebut berusaha untuk melakukan penelitian tentang kualitas/mutu kayu lokal di Pulau Timor sebagai bahan konstruksi.

\section{KAJIAN PUSTAKA}

\subsection{Mengenal Kayu}

Kayu adalah salah satu bahan bangunan yang sudah lama dikenal oleh masyarakat kita dan telah dipakai untuk berbagai keperluan, termasuk sebagai pendukung struktur bangunan. Di Indonesia terdapat banyak sekali jenis pohon yang dihasilkan dari hutan. Bila dibandingkan dengan bahan struktur bangunan yang lain kayu memiliki beberapa keandalan diantaranya :

- Kayu memiliki berat jenis yang ringan sehingga berat sendiri struktur menjadi ringan;

- Mudah dalam pelaksanaan pekerjaan dengan peralatan yang sederhana;

- Struktur bangunan dari kayu lebih aman terhadap bahaya gempa;

- Bahan bangunan dari kayu memiliki nilai estetika yang cukup tinggi;

- Kayu dapat dibudidayakan;

- Sebagai bahan dari alam, kayu dapat terurai secara sempurna sehingga tidak ada istilah limbah pada konstruksi kayu.

Pemakaian kayu sebagai bahan konstruksi tidak sepesat pemakaian bahan beton atau baja disebabkan oleh :

a.Panjang kayu yang terbatas.

b.Kekuatan kayu relatif kecil.

c.Penampang kayu kecil.

d.Mudah terbakar.

e. Mudah terpengaruh oleh zat-zat kimia

f. Peka sekali terhadap kadar air.

g. Sifat kembang-susutnya besar 
Pada masa lalu perancangan konstruksi kayu dilakukan secara intuitif dan coba-coba sehingga pemanfaatan kayu menjadi kurang optimal dan cenderung boros. Akan tetapi dengan penguasaan teknologi pada saat ini dimana teknik-teknik analisis dan perencanaan sudah semakin berkembang, maka perencanaan konstruksi kayu dapat dilakukan secara rasional dan mengikuti ketentuan-ketentuan yang berlaku sehingga pemakaian kayu menjadi lebih efektif dan ekonomis.

\subsection{Anatomi Kayu}

Senyawa utama penyusun sel kayu adalah selulosa, hemiselulosa, dan lignin dengan komposisi kira-kira $50 \%$ selulosa, 25\% hemiselulosa, dan 25\% lignin (Desch dkk, 1981, dalam Alimudin dan Irawati, 2005). Sel-sel kayu ini kemudian secara berkelompok membentuk pembuluh, parenkim, dan serat. Pembuluh memiliki bentuk seperti pipa yang berfungsi untuk saluran air dan zat hara. Parenkim memiliki bentuk kotak, berdinding tipis dan berfungsi sebagai tempat penyimpanan sementara hasil fotosintesis. Sedangkan serat memiliki bentuk panjang langsing dan berdinding tebal serta berfungsi sebagai penguat pohon.

Kelompok sel kayu bergabung membentuk bagian/anatomi pohon seperti pada Gambar 1 . Bagian luar kayu yang disebut kulit (bark), merupakan lapisan yang padat dan cukup kasar. Pada bagian sebelah dalam kulit terdapat lapisan tipis yang disebut lapisan kambium, lapisan ini merupakan tempat pertumbuhan sel-sel kayu. Di sebelah dalam lapisan kambium terdapat bagian kayu lunak yang berwarna keputih-putihan disebut kayu gubal (sapwood), bagian ini berfungsi sebagai penghantar zat-zat makanan dari akar menuju daun, dan dapat pula berfungsi sebagai tempat menyimpan bahan makanan. Karena itu jika dipakai sebagai bahan konstruksi, bagian kayu ini akan cepat lapuk. Tebalnya lapisan kayu gubal ini kira-kira $2 \mathrm{~cm}$ sampai $10 \mathrm{~cm}$ dan relatif tetap demikian sepanjang hidup pohon (Mandang dkk, 1997).

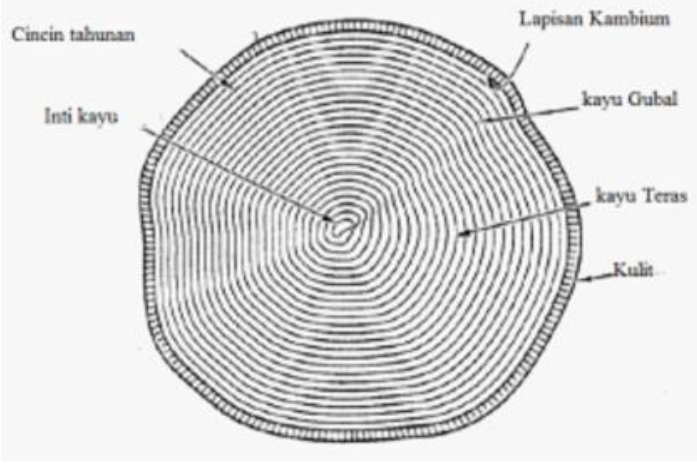

Gambar 1. Potongan melintang pohon kayu

Warna kayu berubah menjadi lebih tua karena pengendapan zat-zat ekstraktif. Lapisan kayu ini dikenal dengan nama teras (heartwood) dengan fungsi sebagai penguat pohon. Karena pada kayu teras tidak terdapat zat-zat makanan, maka bagian kayu ini jika digunakan sebagai bahan konstruksi akan lebih awet.

Pertumbuhan sel-sel kayu ini disertai dengan munculnya struktur seperti cincin yang disebut dengan cincin tahunan (annual ring). Pohon kayu yang mengalami pertumbuhan cepat akan memiliki cincin tahunan yang lebih lebar jika dibandingkan dengan pohon kayu yang memiliki pertumbuhan lambat. Pada bagian tengah batang disebut inti (pith) yang dikelilingi oleh sejumlah cincin tahunan yang dapat memperkirakan umur dari pohon kayu tersebut.

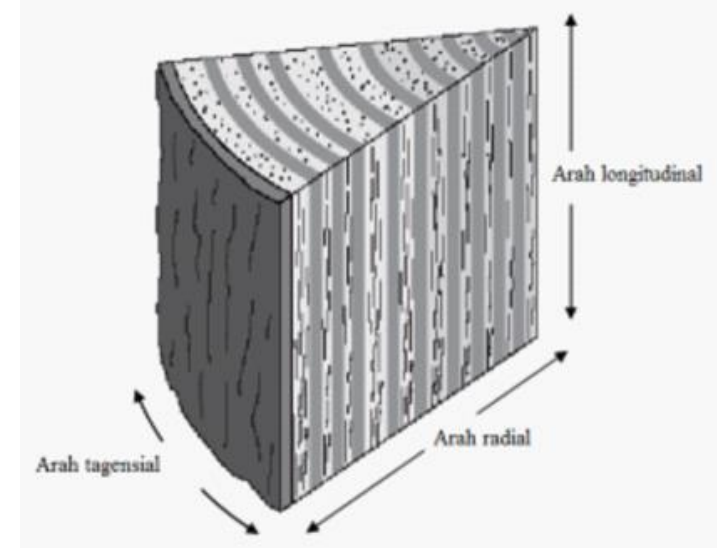

Gambar 2. Arah longitudinal, radial, dan tangensial pada pohon kayu,

(American Forest Product Laboratory, 1991) 


\subsection{Sifat-sifat Fisis Kayu}

\section{Kandungan air / Kadar Lengas Kayu}

Kayu merupakan bahan higroskopis, artinya kayu memiliki kaitan yang sangat erat dengan air. Kemampuan menyerap dan melepaskan air sangat tergantung dari kondisi lingkungan seperti temperatur dan kelembaban udara. Kandungan air yang terdapat pada sebuah pohon kayu sangat bervariasi tergantung pada spesiesnya. Dalam satu spesies yang sama terjadi pula perbedaan kandungan air yang disebabkan oleh umur, ukuran pohon dan lokasi pertumbuhannya. Pada bagian batang sebuah pohon kayu terjadi perbedaan kandungan air, dimana pada kayu gubal lebih banyak dari pada kayu teras.Air yang terdapat pada batang kayu tersimpan dalam dua bentuk yaitu air bebas (free water) yang terletak diantara sel-sel kayu, dan air ikat (bound water) yang terletak pada dinding sel. Selama air bebas masih ada, maka dindingdinding sel kayu akan tetap jenuh. Air bebas merupakan air yang pertama yang akan berkurang seiring dengan proses pengeringan, dan pengeringan selanjutnya akan dapat mengurangi air ikat pada dinding sel. Ketika batang kayu mulai diolah (ditebang dan dibentuk), kandungan air pada batang berkisar antara $40 \%$ hingga 300\%. Kandungan air ini dinamakan kandungan air segar. Setelah ditebang dan dimulai dibentuk atau diolah, kandungan air mulai bergerak keluar. Suatu kondisi dimana air bebas yang berada di antara sel-sel sudah habis sedangkan air ikat yang berada pada dinding sel masih jenuh dinamakan titik jenuh serat (fiber saturation point). Kandungan air pada kondisi ini berkisar antara $25 \%$ hingga $30 \%$.

Pengeringan selanjutnya (di bawah titik jenuh serat) akan mengurangi kandunga air ikat pada dinding sel, dan hal ini akan menyebabkan terjadinya perubahan dimensi tampang melintang batang kayu, perubahan sifat-sifat mekanis, dan ketahanan lapuk. Kandungan air pada kayu akan sangat dipengaruhi oleh kelembaban udara lingkungan. Bila kelembaban udara lingkungan meningkat, maka kandungan air pada kayu juga akan meningkat, dan begitupun sebaliknya. Pada lingkungan yang memiliki kelembaban udara yang stabil, maka kandungan air pada kayu juga akan cenderung tetap. Kondisi kandungan air yang tetap pada kayu ini disebut kadar air imbang (equilibrium moisture content).

Perhitungan kadar air/kadar lengas kayu didasarkan menurut persamaan :

Kadar air/kadar lengas $=\frac{\mathrm{B}_{0}-\mathrm{B}_{1}}{\mathrm{~B}_{\mathrm{O}}} \cdot 100 \%$

\section{Kerapatan dan Berat Jenis}

Kerapatan / berat volume kayu dinyatakan sebagai berat per unit volume. Pengukuran kerapatan dimaksudkan untuk mengetahui porositas atau persentase rongga (void) pada kayu. Kerapatan dan volume sangat bergantung pada kandungan air.

Berat jenis adalah perbandingan antara berat kayu tanpa air dengan berat air pada volume yang sama. Kayu terdiri dari bagian padat (sel kayu), air dan udara. Berat jenis kayu mempunyai korelasi yang positif dengan kekuatan kayu. Semakin tinggi berat jenis kayu semakin baik kekuatannya dan begitupun sebaliknya.

Perhitungan kerapatan kayu dan berat jenis

didasarkan menurut persamaan :
Kerapatan $=$ Berat Volume Basah $\left(\gamma_{\mathrm{b}}\right)=\frac{\text { Bo }}{\text { Vo }}$

Berat volume kering $\left(\gamma_{d}\right)=\frac{B 1}{V 1}$

Berat Jenis $g=\frac{\gamma d}{\gamma \mathrm{w}}$

Dengan : Bo : Berat awal (gram)

B1 : Berat kering kayu (gram)

Vo : Volume awal $(\mathrm{cm} 3)$

V1 : Volume setelah dioven (gram)

\section{Cacat kayu}

Cacat atau kerusakan kayu dapat mengurangi kekuatan dan bahkan kayu yang cacat tersebut tidak dapat dipergunakan sebagai bahan konstruksi. Cacat kayu yang sering terjadi 
Volume 2 Nomor 2 Oktober 2017

adalah retak (cracks), mata kayu (knots), dan kemiringan serat (slope of grain). Retak pada kayu terjadi karena proses penyusutan akibat penurunan kandungan air selama proses pengeringan. Pada batang kayu yang tipis, retak dapat terjadi lebih besar yang disebut dengan belah (split). Mata kayu sering terdapat pada batang kayu yang merupakan bekas cabang kayu. Pada mata kayu ini terjadi pembelokan arah serat, sehingga kekuatan kayu menjadi berkurang. Kemiringan serat menunjukkan sudut miring serat kayu. Kemiringan serat pada batang kayu terjadi disebabkan karena tidak sesuainya sumbu batang kayu dengan sumbu pohon pada saat pemotongan/penggergajian.
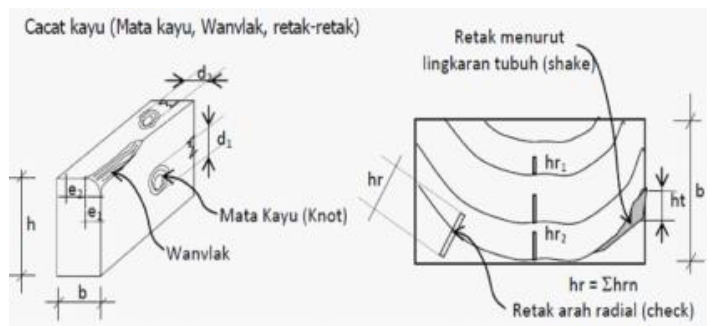

Gambar 3. Cacat Kayu

\section{Miring Arah Serat}

Arah serat kayu tergantung dari pertumbuhan pohon. Jika arah serat kayu tidak searah dengan tepi kayu gergajian disebut serat miring seperti terlihat dalam gambar 4 berikut.

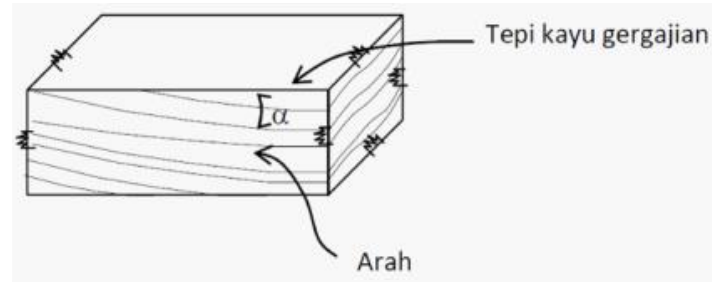

Gambar 4. Arah Serat Kayu

\section{Mutu Kayu}

Mutu kayu menurut SNI dibedakan menjadi 2 jenis yaitu Mutu A dan Mutu B seperti ditampilkan dalam Tabel 1 berikut.
Tabel 1. Mutu Kayu

\begin{tabular}{|c|c|}
\hline MUTU A & MUTU B \\
\hline $\begin{array}{l}\text { 1. Kadar lengas kering udara } \\
12-18 \% \text {; rata-rata } 15 \%\end{array}$ & $\begin{array}{l}\text { 1. Kadar lengas } \\
\leq 30 \%\end{array}$ \\
\hline $\begin{array}{l}\text { 2. Mata kayu } \\
\qquad \begin{array}{l}\mathrm{d}_{1} \leq 1 / 6 \mathrm{~h} ; \mathrm{d}_{2} \leq 1 / 6 \mathrm{~b} \\
\mathrm{~d} 1 \leq 3,5 \mathrm{~cm} ; \mathrm{d} 2 \leq 3,5 \mathrm{~cm}\end{array}\end{array}$ & $\begin{array}{l}\text { 2. Mata Kayu } \\
\begin{aligned} d_{1} & \leq 1 / 4 h ; d_{2} \leq 1 / 4 \mathrm{~b} \\
d_{1} & \leq 5 \mathrm{~cm} ; d_{2} \leq 5 \mathrm{~cm}\end{aligned}\end{array}$ \\
\hline $\begin{array}{l}\text { 3. Wanvlak } \\
e_{1} \leq 1 / 10 \mathrm{~b} ; \mathrm{e}_{2} \leq 1 / 10 \mathrm{~h} \\
\mathrm{~b}_{2} \text { tinggi balok } \\
\mathrm{h} \text { tinggi balok }\end{array}$ & $\begin{array}{l}\text { 3. Wanvlak } \\
e_{1} \leq 1 / 10 b ; e_{2} \leq 1 / 10 h\end{array}$ \\
\hline $\begin{array}{l}\text { 4. Miring arah serat } \\
\operatorname{Tg} \alpha \leq 1 / 10\end{array}$ & $\begin{array}{l}\text { 4. Miring arah serat } \\
\operatorname{Tg} \alpha \leq 1 / 7\end{array}$ \\
\hline $\begin{array}{l}\text { 5. Retak-retak } \\
\mathrm{Hr} \leq 1 / 4 \mathrm{~b} ; \mathrm{ht} \leq 1 / 5 \mathrm{~b}\end{array}$ & $\begin{array}{l}\text { 5. Retak-retak } \\
H \leq 1 / 3 \mathrm{~b} ; \text { ht } \leq 1 / 4 \mathrm{~b}\end{array}$ \\
\hline
\end{tabular}

\section{Tegangan Ijin Kayu}

Tegangan yang diijinkan untuk kayu mutu A seperti ditampilkan dalam Tabel 2 berikut berdasarkan Kelas Kuat Kayu yang terdapat dalam PKKI Tahun 1961. Untuk kayu mutu B dikalikan dengan $\mathrm{f}=0,75$.

Tabel 2. Tegangan Ijin Kay

\begin{tabular}{|l|l|l|l|l|l|l|}
\hline \multirow{2}{*}{ Tegangan } & \multicolumn{5}{|c|}{ Kelas Kuat } & \multirow{2}{*}{ Jati } \\
\cline { 2 - 6 } & I & II & III & IV & V & \\
\hline $\bar{\sigma}_{t /}\left(\mathrm{kg} / \mathrm{cm}^{2}\right)$ & 150 & 100 & 75 & 50 & - & 130 \\
$\bar{\sigma}_{t k} / /=\bar{\sigma}_{t} / /\left(\mathrm{kg} / \mathrm{cm}^{2}\right)$ & 130 & 85 & 60 & 45 & - & 110 \\
$\bar{\sigma}_{t k} \perp\left(\mathrm{kg} / \mathrm{cm}^{2}\right)$ & 40 & 25 & 15 & 10 & - & 30 \\
$\bar{\tau}_{/ /(}\left(\mathrm{kg} / \mathrm{cm}^{2}\right)$ & 20 & 12 & 8 & 5 & - & 15 \\
\hline
\end{tabular}

Korelasi tegangan ijin untuk kayu mutu A yang dihubungkan dengan nilai $\mathrm{g}$ (berat jenis kayu kering udara) adalah sebagai berikut :

$$
\begin{aligned}
& \bar{\sigma}_{t t}=170 \mathrm{~g} \\
& \bar{\sigma}_{t k} / /=\bar{\sigma}_{t r} / /=150 \mathrm{~g} \\
& \bar{\sigma}_{t k} \perp=40 \mathrm{~g} \\
& \bar{\tau} / /=20 \mathrm{~g} \\
& \text { Dimana : } \\
& \mathrm{g} \quad=\text { berat jenis kayu kering udara } \\
& \bar{\sigma}_{t t} \quad=\text { Tegangan ijin untuk lentur } \\
& \bar{\sigma}_{t k} / /=\text { Tegangan ijin sejajar serat untuk tekan }
\end{aligned}
$$


$\bar{\sigma}_{r r} / /=$ Tegangan ijin sejajar serat untuk tarik

$\bar{\sigma}_{t k} \perp=$ Tegangan ijin tegak lurus serat untuk tekan

$\bar{\tau} / /=$ Tegangan ijin sejajar serat untuk geser

\section{Modulus Elastisitas dan Modulus Geser}

Modulus elastisitas searah serat kayu (E) dan modulus geser searah serat kayu (C) ditampilkan dalam Tabel 3 berikut.

Tabel 3. Modulus elastisitas // kayu dan modulus geser // kayu

\begin{tabular}{|l|l|l|}
\hline Kelas Kuat Kayu & $\mathrm{E} / /\left(\mathrm{kg} / \mathrm{cm}^{2}\right)$ & $\mathrm{C} / /\left(\mathrm{kg} / \mathrm{cm}^{2}\right)$ \\
\hline I & 125.000 & 10.000 \\
II & 100.000 & 5.000 \\
III & 80.000 & 5.000 \\
IV & 60.000 & - \\
\hline
\end{tabular}

\section{Kekuatan Kayu}

Kekuatan kayu berdasarkan kelas kuat dan berat jenis ditampilkan dalam Tabel 4 berikut.

Tabel 4. Kekuatan kayu berdasarkan kelas kuat dan berat jenis

\begin{tabular}{|l|l|l|l|}
\hline Kelas Kuat Kayu & $\begin{array}{c}\text { Berat Jenis kering } \\
\text { udara }\end{array}$ & $\begin{array}{r}\text { Kukuh lentur mutlak } \\
\left(\mathrm{kg} / \mathrm{cm}^{2}\right)\end{array}$ & $\begin{array}{c}\text { Kukuh tekan mutlak } \\
\left(\mathrm{kg} / \mathrm{cm}^{2}\right)\end{array}$ \\
\hline I & $\geq 0,90$ & $\geq 1100$ & $\geq 650$ \\
II & $0,90-0,60$ & $1100-725$ & $650-425$ \\
III & $0,60-0,40$ & $725-500$ & $425-300$ \\
IV & $0,40-0,30$ & $500-360$ & $300-215$ \\
V & $\leq 0,30$ & $\leq 360$ & $\leq 215$ \\
\hline
\end{tabular}

Selanjutnya tegangan dasar kayu (basic stress) untuk kayu basah dan kering menurut SII. 0458-81 ditampilkan dalam Tabel 5 berikut.

Tabel 5. Kekuatan kayu berdasarkan SII. 045881

\begin{tabular}{|l|l|l|l|c|}
\hline No. & \multicolumn{1}{|c|}{ Uraian } & \multicolumn{1}{|c|}{ Tegangan } & Kayu basah & Kayu Kering \\
\hline 1 & $\begin{array}{l}\text { Modulus Elastisitas } \\
\left(1000 \mathrm{Kk} / \mathrm{cm}^{2}\right)\end{array}$ & dasar & $97,3 \mathrm{C}+13,1$ & $105,1 \mathrm{C}+14,1$ \\
\hline 2 & $\begin{array}{l}\text { Tegangan lentur } \\
\left(\mathrm{Kg} / \mathrm{cm}^{2}\right)\end{array}$ & dasar & $303,2 \mathrm{C}$ & $340,8 \mathrm{C}$ \\
\hline 3 & $\begin{array}{l}\text { Tegangan tekan dan } \\
\text { tarik // serat }\left(\mathrm{Kg} / \mathrm{cm}^{2}\right)\end{array}$ & dasar & $297,5 \mathrm{C}-6,2$ & $341,3 \mathrm{C}-7,11$ \\
\hline 4 & $\begin{array}{l}\text { Tegangan tekan 1 } \\
\text { serat }\left(\mathrm{Kg} / \mathrm{cm}^{2}\right)\end{array}$ & dasar & $126,6 \mathrm{C}-37,4$ & $143,5 \mathrm{C}-42,4$ \\
\hline 5 & $\begin{array}{l}\text { Tegangan geser /I } \\
\text { serat }\left(\mathrm{Kg} / \mathrm{cm}^{2}\right)\end{array}$ & dasar & $48,5 \mathrm{C}-7,3$ & $51,1 \mathrm{C}-7,7$ \\
\hline
\end{tabular}

\section{METODE PENELITIAN}

\subsection{Lokasi Penelitian}

Lokasi pelaksanaan penelitian dilaksanakan di Laboratorium Jurusan Teknik Sipil Politeknik Negeri Kupang, Kota Kupang - Nusa Tenggara Timur.

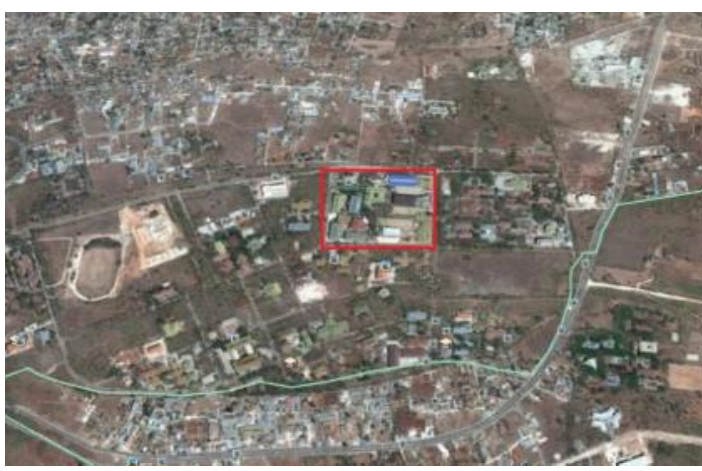

Gambar 3.1. Peta Lokasi pelaksanaan penelitian Laboratorium Jurusan Teknik Sipil Politeknik Negeri Kupang

Lokasi pengambilan pohon / kayu untuk sampel penelitian dilaksanakan di Desa Oefeto dan Desa Kairane Kecamatan Oefeto Kabupaten Kupang - Nusa Tenggara Timur sebagai salah satu daerah pemasok kayu konstruksi di Kota Kupang.

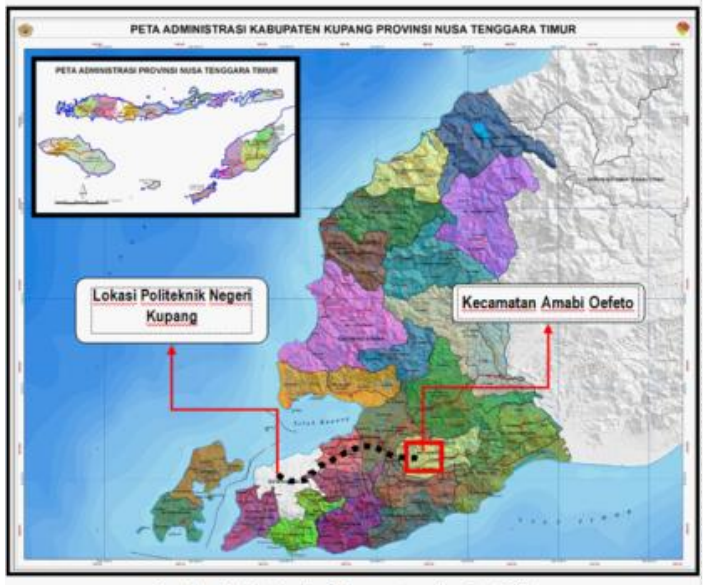

Gambar 1. Peta Lokasi Kecamatan Amabo Oefeto 
Volume 2 Nomor 2 Oktober 2017

\subsection{Waktu Penelitian}

Penelitian ini dilaksanakan dengan durasi waktu 6 bulan sejak bulan Juni sampai dengan Desember 2017.

\subsection{Tahapan Penelitian}

Adapun tahapan penelitian sebagai berikut: 1.Pemilihan Jenis Kayu Lokal

Jenis-jenis kayu lokal yang diteliti adalah beberapa jenis kayu lokal Timor yang sering dipasok sebagai kayu kontruksi di Kota Kupang antara lain : Kayu Kabesak, Johar (Kayu Besi), Jati Putih (Gamalina), Jambu Air, Ketapang Hutan dan Mahoni.

Pemilihan kayu sampel juga dibatasi pada pohon yang berumur minimal 20 tahun atau berdiameter minimum $30 \mathrm{~cm}$.

2.Pengambilan Sampel Kayu

Setelah penebangan dilakukan, bagian pohon yang diambil meliputi bagian bawah, tengah dan atas dari bagian yang lurus (bukan cabang) dan selanjutnya bagian-bagian ini dibagi lagi menjadi sampel-sampel pengujian kadar air, berat jenis dan pengujian kuat tekan searah serat kayu. Data yang dikumpulkan dari pengambilan Sampel (Sampling) berupa data primer dengan rancangan masing-masing bagian pohon (bawah, tengah dan atas) diambil 9 unit sampel untuk masing-masing pengujian sehingga total terdapat 54 sampel pada setiap jenis kayu / pohon.

3.Pengujian Sampel Kayu

Pengujian Kayu meliputi :

a.Pengujian Kadar Air atau Kadar Lengas

Kayu (SNI 03-6850-2002).

b.Pengujian Berat Jenis Kayu (SNI 03-68482002).

c. Pengujian Kuat Tekan Kayu (SNI 03-39581995).

\section{HASIL DAN PEMBAHASAN}

Hasil Pengujian dapat disajikan dalam tabel berikut ini,

4.1.Pengujian Kadar Air Kayu (SNI 03-68502002)
Tabel 4.1. Kayu Gamalina

\begin{tabular}{|c|c|c|c|c|}
\hline No. Sampel & $\begin{array}{c}\text { Berat Awal } \\
\text { (Gram) }\end{array}$ & $\begin{array}{l}\text { Berat Oven } \\
\text { (Gram) }\end{array}$ & Kadar Alr & $\begin{array}{c}\text { Kadar Alr Rata } \\
\text { rata }\end{array}$ \\
\hline B1 & 316.3 & 272.5 & $16.07 \%$ & \multirow{3}{*}{$17.67 \%$} \\
\hline B1 & 271.9 & 236.5 & $14.97 \%$ & \\
\hline B1 & 277.0 & 227.1 & $21.97 \%$ & \\
\hline$B 2$ & 310.7 & 265.7 & $16.94 \%$ & \multirow{3}{*}{$18.30 \%$} \\
\hline$B 2$ & 324.6 & 274.8 & $18.12 \%$ & \\
\hline 82 & 304.5 & 254.1 & $19.83 \%$ & \\
\hline B3 & 276.3 & 234.5 & $17.83 \%$ & \multirow{3}{*}{$17.66 \%$} \\
\hline $\mathrm{B} 3$ & 320.2 & 268.3 & $19.34 \%$ & \\
\hline $\mathrm{B3}$ & 279.9 & 241.7 & $15.80 \%$ & \\
\hline
\end{tabular}

Sumber : Hasill Analisa Penulls 2017

Tabel 4.2. Kayu Kabesak

\begin{tabular}{|c|c|c|c|c|}
\hline No. Sampel & $\begin{array}{c}\text { Berat Awal } \\
\text { (Gram) }\end{array}$ & $\begin{array}{c}\text { Berat Oven } \\
\text { (Gram) }\end{array}$ & Kadar Alr & $\begin{array}{c}\text { Kadar Alr Rata } \\
\text { rata }\end{array}$ \\
\hline B1 & 379.4 & 315.3 & $20.33 \%$ & \multirow{3}{*}{$17.73 \%$} \\
\hline B1 & $355 . A$ & 304.5 & $16.72 \%$ & \\
\hline B1 & 368.3 & 317.1 & $16.15 \%$ & \\
\hline B2 & 361.7 & 309.1 & $17.02 \%$ & \multirow{3}{*}{$17.23 \%$} \\
\hline B2 & 358.5 & 302.1 & $18.67 \%$ & \\
\hline$B 2$ & 342.8 & 295.5 & $16.01 \%$ & \\
\hline B3 & 344.7 & 297.6 & $15.83 \%$ & \multirow{3}{*}{$16.80 \%$} \\
\hline 83 & 3620 & 305.2 & $18.61 \%$ & \\
\hline B3 & 343.6 & 296.3 & $15.96 \%$ & \\
\hline
\end{tabular}

Sumber : Hasil Anallsa Penuls 2017

Tabel 4.3. Kayu Johar

\begin{tabular}{|c|c|c|c|c|}
\hline No. sampel & $\begin{array}{l}\text { Berat Awal } \\
\text { (Gram) }\end{array}$ & $\begin{array}{l}\text { Berat Oven } \\
\text { (Gram) }\end{array}$ & Kadar Alr & $\begin{array}{c}\text { Kadar Alr Rata- } \\
\text { rata }\end{array}$ \\
\hline B1 & 470.6 & 393.0 & $19.75 \%$ & \multirow{3}{*}{$16.83 \%$} \\
\hline B1 & 482.4 & 420.9 & $14.61 \%$ & \\
\hline B1 & 486.9 & 419.3 & $16.12 \%$ & \\
\hline B2 & 454.0 & 379.7 & $19.57 \%$ & \multirow{3}{*}{$18.75 \%$} \\
\hline B2 & $491 . A$ & 417.0 & $17.84 \%$ & \\
\hline$B 2$ & 486.3 & 409.2 & $18.84 \%$ & \\
\hline$B 3$ & 4912 & 412.5 & $19.08 \%$ & \multirow{3}{*}{$18.36 \%$} \\
\hline B3 & 513.9 & 438.7 & $17.14 \%$ & \\
\hline B3 & 506.9 & 426.5 & $18.85 \%$ & \\
\hline
\end{tabular}

Sumber : Hasil Analisa Penulls 2017

Tabel 4.4. Kayu Jambu Air

\begin{tabular}{|c|c|c|c|c|}
\hline No. S ampel & $\begin{array}{l}\text { Berat Awal } \\
\text { (Gram) }\end{array}$ & $\begin{array}{l}\text { Berat Oven } \\
\text { (Gram) }\end{array}$ & Kadar Alr & $\begin{array}{c}\text { Kadar Alr Rata } \\
\text { rata }\end{array}$ \\
\hline B1 & 401.3 & 335.7 & $19.54 \%$ & \multirow{3}{*}{$19.90 \%$} \\
\hline B1 & 405.2 & 340.3 & $19.07 \%$ & \\
\hline B1 & 400.3 & 330.6 & $21.08 \%$ & \\
\hline$B 2$ & 396.7 & 338.5 & $17.19 \%$ & \multirow{3}{*}{$17.91 \%$} \\
\hline$B 2$ & 392.2 & 339.5 & $15.39 \%$ & \\
\hline B2 & 366.0 & 302.1 & $21.15 \%$ & \\
\hline B3 & 390.2 & 329.5 & $18.42 \%$ & \multirow{3}{*}{$18.79 \%$} \\
\hline B3 & 395.1] & 336.8 & $17.31 \%$ & \\
\hline E3 & 397.0 & 329.1 & $20.63 \%$ & \\
\hline
\end{tabular}


Tabel 4.5. Ketapang Hutan

\begin{tabular}{|c|c|c|c|c|}
\hline No. Sampel & $\begin{array}{c}\text { Berat Awal } \\
\text { (Gram) }\end{array}$ & $\begin{array}{c}\text { Berat Oven } \\
\text { (Gram) }\end{array}$ & Kadar Alr & $\begin{array}{c}\text { Kadar Alr Rata } \\
\text { rata }\end{array}$ \\
\hline B1 & 335.8 & 288.4 & $16.44 \%$ & \multirow{3}{*}{$16.47 \%$} \\
\hline B1 & 338.1 & 294.6 & $14.77 \%$ & \\
\hline B1 & 342.8 & 290.0 & $18.21 \%$ & \\
\hline B2 & 328.9 & 291.0 & $13.02 \%$ & \multirow{3}{*}{$17.72 \%$} \\
\hline B2 & 340.5 & 283.0 & $20.32 \%$ & \\
\hline B2 & 338.5 & 282.6 & $19.82 \%$ & \\
\hline 83 & 336.0 & 283.4 & $18.56 \%$ & \multirow{3}{*}{$18.85 \%$} \\
\hline 83 & 331.4 & 278.8 & $18.87 \%$ & \\
\hline B3 & 329.7 & 276.8 & $19.11 \%$ & \\
\hline
\end{tabular}

Tabel 4.6. Kayu Mahoni

\begin{tabular}{|c|c|c|c|c|}
\hline No. Sampel & $\begin{array}{c}\text { Berat Awal } \\
\text { (Gram) }\end{array}$ & $\begin{array}{c}\text { Berat Oven } \\
\text { (Gram) }\end{array}$ & Kadar Alr & $\begin{array}{c}\text { Kadar Air Rata } \\
\text { rata }\end{array}$ \\
\hline B1 & 325.4 & 278.6 & $16.80 \%$ & \multirow{3}{*}{$18.59 \%$} \\
\hline B1 & 3150 & 261.7 & $20.37 \%$ & \\
\hline B1 & 316.0 & 266.4 & $18.62 \%$ & \\
\hline B2 & 305.8 & 260.2 & $17.52 \%$ & \multirow{3}{*}{$18.06 \%$} \\
\hline$B 2$ & 308.4 & 260.0 & $18.62 \%$ & \\
\hline$B 2$ & 308.1 & 261.0 & $18.05 \%$ & \\
\hline E3 & 300.4 & 248.6 & $20.84 \%$ & \multirow{3}{*}{$18.73 \%$} \\
\hline B3 & 301.9 & 254.1 & $18.81 \%$ & \\
\hline$B 3$ & 298.5 & 256.1 & $16.56 \%$ & \\
\hline
\end{tabular}

4.2. Pengujian Berat Jenis Kayu (SNI 03-68482002)

Tabel 4.7. Kayu Gamalina

\begin{tabular}{|c|c|c|c|c|c|c|c|c|}
\hline \multirow{2}{*}{$\begin{array}{c}\text { No. } \\
\text { Sampel }\end{array}$} & \multicolumn{3}{|c|}{ Dimensi Kayu } & \multirow{2}{*}{$\begin{array}{l}\text { Volume } \\
\left(\mathrm{cm}^{2}\right)\end{array}$} & \multirow{2}{*}{$\begin{array}{c}\text { Berat Awal } \\
\text { (Gram) }\end{array}$} & \multirow{2}{*}{$\begin{array}{l}\text { Berat Oven } \\
\text { (Gram) }\end{array}$} & \multirow{2}{*}{ Berat Jenis } & \multirow{2}{*}{ Rata-ata } \\
\hline & $p(\mathrm{~cm})$ & $I(\mathrm{~cm})$ & $t(\mathrm{~cm})$ & & & & & \\
\hline B1 & 20.00 & 4.90 & 5.00 & 400.00 & 316.3 & 272.5 & 0.56 & \multirow{3}{*}{0.50} \\
\hline B1 & 20.00 & 4.90 & 5.00 & 400.00 & 271.8 & 238.5 & 0.48 & \\
\hline B1 & 20.00 & 4.90 & 5.00 & 400.00 & 277.0 & 227.1 & 0.46 & \\
\hline$B 2$ & 2000 & 4.90 & 5.00 & 480.00 & 310.7 & 265.7 & 0.54 & \multirow{3}{*}{0.54} \\
\hline$B 2$ & 20.00 & 4.90 & 5.00 & 480.00 & 324.6 & 274.8 & 0.56 & \\
\hline$B 2$ & 20.00 & 4.90 & 5.00 & 420.00 & 304.5 & 254.1 & 0.52 & \\
\hline B3 & 2000 & 4.90 & 5.00 & 40000 & 270.3 & 234.5 & 0.48 & \multirow{3}{*}{0.51} \\
\hline B3 & 2000 & 4.90 & 5.00 & 480.00 & 3202 & 268.3 & 0.58 & \\
\hline B3 & 20.00 & 4.80 & 5.00 & 490.00 & 270.8 & 241.7 & 0.49 & \\
\hline
\end{tabular}

Sumber : Hasil Analisa Penulis 2017
Tabel 4.8. Kayu Kabesak

\begin{tabular}{|c|c|c|c|c|c|c|c|c|}
\hline \multirow{2}{*}{$\begin{array}{c}\text { No. } \\
\text { Sampel }\end{array}$} & \multicolumn{3}{|c|}{ Dimensi Kayu } & \multirow{2}{*}{$\begin{array}{c}\text { Volume } \\
\left(\mathrm{cm}^{\prime}\right)\end{array}$} & \multirow{2}{*}{$\begin{array}{c}\text { Berat Awal } \\
\text { (Gram) }\end{array}$} & \multirow{2}{*}{$\begin{array}{c}\text { Berat Oven } \\
\text { (Gram) }\end{array}$} & \multirow{2}{*}{ Berat Jenis } & \multirow{2}{*}{ Ratarate } \\
\hline & $\mathrm{p}(\mathrm{cm})$ & $1(\mathrm{~cm})$ & $t(\mathrm{~cm})$ & & & & & \\
\hline B1 & 20.00 & 5.00 & 5.00 & 500.00 & 370.4 & 315.3 & 0.03 & \multirow{3}{*}{0.62} \\
\hline B1 & 20.000 & 5.00 & 5.00 & 500.00 & 366.4 & 304.5 & 0.01 & \\
\hline B1 & 20,00 & 5.00 & 5.00 & 500.00 & 368.3 & 317.1 & 0.83 & \\
\hline 82 & 2000 & 5.00 & 5.00 & 500.00 & 361.7 & 300.1 & 0.62 & \multirow{3}{*}{0.60} \\
\hline 82 & 2000 & 5.00 & 5.00 & 500000 & 368.5 & 302.1 & 0.80 & \\
\hline 82 & 20,00 & 5.00 & 5.00 & 500.00 & 342.8 & 225.5 & 0.59 & \\
\hline 83 & 20.00 & 5.00 & 5.00 & 500.00 & 344.7 & 287.8 & 0.80 & \multirow{3}{*}{0.60} \\
\hline 83 & 20.00 & 5.00 & 5.00 & 500.00 & 3620 & 305.2 & 0.81 & \\
\hline B3 & 20.00 & 5.00 & 5.00 & 500.00 & 343.6 & 286.3 & 0.50 & \\
\hline
\end{tabular}

Sumber : Hasi Analisa Penulis 2017

Tabel 4.9. Kayu Johar

\begin{tabular}{|c|c|c|c|c|c|c|c|c|}
\hline \multirow{2}{*}{$\begin{array}{c}\text { No. } \\
\text { Sampel }\end{array}$} & \multicolumn{3}{|c|}{ Dimensi Kayu } & \multirow{2}{*}{$\begin{array}{l}\text { Volume } \\
\left(\mathrm{cm}^{\prime}\right)\end{array}$} & \multirow{2}{*}{$\begin{array}{c}\text { Berat Awal } \\
\text { (Gram) }\end{array}$} & \multirow{2}{*}{$\begin{array}{c}\text { Berat Oven } \\
\text { (Gram) }\end{array}$} & \multirow{2}{*}{ |Berat Jenis } & \multirow{2}{*}{ Ratarate } \\
\hline & $p(\mathrm{~cm})$ & $1(\mathrm{~cm})$ & $t(\mathrm{~cm})$ & & & & & \\
\hline B1 & 20000 & 5.00 & 5.00 & 500.00 & 470.6 & 3030 & 0.70 & \multirow{3}{*}{0.82} \\
\hline B1 & 2000 & 5.00 & 5.00 & 500.00 & 4824 & 420.9 & 0.94 & \\
\hline B1 & 20.00 & 5.00 & 5.00 & 500.00 & 488.0 & 410.3 & 0.84 & \\
\hline$B 2$ & 20.00 & 5.00 & 5.00 & 300.00 & 454.0 & 372.7 & 0.76 & \multirow{3}{*}{0.80} \\
\hline$B 2$ & 20.00 & 5.00 & 5.00 & 500.00 & 491.4 & 4170 & 0.83 & \\
\hline 82 & 20.00 & 5.00 & 5.00 & 500.00 & 480.3 & 400.2 & 0.82 & \\
\hline B3 & 20.00 & 5.00 & 5.00 & 500.00 & 401.2 & 412.5 & 0.83 & \multirow{3}{*}{0.85} \\
\hline$B 3$ & 2000 & 5.00 & 5.00 & 500.00 & 513.9 & 438.7 & 0.88 & \\
\hline B3 & 20.00 & 5.00 & 5.00 & 500.00 & 506.9 & 428.5 & 0.85 & \\
\hline
\end{tabular}

Sumber: Hasil Analisa Penulis 2017

Tabel 4.10. Kayu Jambu Air

\begin{tabular}{|c|c|c|c|c|c|c|c|c|}
\hline \multirow{2}{*}{$\begin{array}{c}\text { No. } \\
\text { Sampel }\end{array}$} & \multicolumn{3}{|c|}{ Dimensi Kayu } & \multirow{2}{*}{$\begin{array}{l}\text { Volume } \\
\left(\mathrm{cm}^{\prime}\right)\end{array}$} & \multirow{2}{*}{$\begin{array}{c}\text { Berat Awal } \\
\text { (Gram) }\end{array}$} & \multirow{2}{*}{$\begin{array}{c}\text { Berat Oven } \\
\text { (Gram) }\end{array}$} & \multirow{2}{*}{ Berat Jenis } & \multirow{2}{*}{ Ratarata } \\
\hline & $p(\mathrm{~cm})$ & $1(\mathrm{~cm})$ & $t(\mathrm{~cm})$ & & & & & \\
\hline B1 & 2000 & 6.00 & 5.000 & 800.00 & 401.3 & 335.7 & 0.67 & \multirow{3}{*}{0.67} \\
\hline B1 & 20.00 & 5.00 & 5.00 & 500.00 & 405.2 & 340.3 & 0.88 & \\
\hline B1 & 20.00 & 500 & 5.00 & 500.00 & 400.3 & 300.6 & 0.66 & \\
\hline$B 2$ & 20.00 & 5.00 & 5.00 & 500.00 & 390.7 & 339.6 & 0.68 & \multirow{3}{*}{0.65} \\
\hline 82 & 20.00 & 8.00 & 5.00 & 500.00 & 302.2 & 339.9 & 0.68 & \\
\hline$B 2$ & 20.00 & 500 & 5.00 & 500.00 & 360.0 & 302.1 & 0.80 & \\
\hline B3 & 20.00 & 500 & 5.00 & 500.00 & 390.2 & 320.5 & 0.86 & \multirow{3}{*}{0.68} \\
\hline B3 & 2000 & 500 & 5.00 & 500.00 & 385.1 & 330.8 & 0.67 & \\
\hline B3 & 20.00 & 8.00 & 5.000 & 500.00 & 307.0 & 320.1 & 0.06 & \\
\hline
\end{tabular}

Sumber : Hasi Analsa Penulis 2017 
$\square \quad 147 \mid \begin{array}{lllll} & \text { JUTEKS Jurnal Teknik Sipil } & \text { Volume } 2 & \text { Nomor } 2 & \text { Oktober } 2017\end{array}$

Tabel 4.11. Kayu Ketapang Hutan

\begin{tabular}{|c|c|c|c|c|c|c|c|c|}
\hline \multirow{2}{*}{$\begin{array}{l}\text { Mo. } \\
\text { sampen }\end{array}$} & \multicolumn{3}{|c|}{ Dimenel Kayu } & \multirow{2}{*}{$\begin{array}{l}\text { Volume } \\
\text { (om') }\end{array}$} & \multirow{2}{*}{$\begin{array}{l}\text { Eerat Awal } \\
\text { (Oram) }\end{array}$} & \multirow{2}{*}{$\begin{array}{l}\text { Borst Oven } \\
\text { (Orrm) }\end{array}$} & \multirow{2}{*}{ Berst Jonk } & \multirow{2}{*}{ Ratarta } \\
\hline & $D(\mathrm{om})$ & $I(\infty \mathrm{m})$ & $t(\mathrm{om})$ & & & & & \\
\hline B1 & 2000 & 500 & 500 & 50000 & 335.8 & 288.4 & 0.50 & \multirow{3}{*}{0.68} \\
\hline B1 & 2000 & 500 & 5.00 & 50000 & 338.1 & 234.6 & 0.59 & \\
\hline B1 & 2000 & 500 & 500 & 50000 & 3428 & 290. & 0.58 & \\
\hline 82 & 2000 & 500 & 5.00 & 50000 & 328.9 & 291.0 & 0.50 & \multirow{3}{*}{0.67} \\
\hline B2 & 2000 & 500 & 5.00 & 50000 & 3405 & $283 \mathrm{c}$ & 0.57 & \\
\hline B2 & 2000 & 500 & 5.00 & 50000 & 3386 & 2826 & 0.57 & \\
\hline B3 & 20.00 & 500 & 5.00 & 50000 & 336. & 283.4 & 0.57 & \multirow{3}{*}{0.68} \\
\hline 63 & 2000 & 500 & 5.00 & 50000 & 331.4 & 278.8 & 0.56 & \\
\hline B3 & 2000 & 5.50 & 5.00 & 50000 & 329.7 & 276.8 & 0.56 & \\
\hline
\end{tabular}

Surber: Kal Nala Penule 2017

Tabel 4.12. Kayu Mahoni

\begin{tabular}{|c|c|c|c|c|c|c|c|c|}
\hline \multirow{2}{*}{ Mo. } & \multicolumn{3}{|c|}{ Dimenel Kayu } & \multirow{2}{*}{$\begin{array}{c}\text { Volumb } \\
\text { (om') }\end{array}$} & \multirow{2}{*}{$\begin{array}{c}\text { Eorat Awal } \\
\text { (Oram) }\end{array}$} & \multirow{2}{*}{$\begin{array}{l}\text { Eerat Oven } \\
\text { (Orrm) }\end{array}$} & \multirow{2}{*}{ Berat Jonik } & \multirow{2}{*}{ Ratartit: } \\
\hline & $D(0 \mathrm{~m})$ & $1(\mathrm{~cm})$ & $t(0 \mathrm{~m})$ & & & & & \\
\hline 81 & 2000 & 500 & 5.00 & 500.80 & 325. & 278.6 & 0.56 & \multirow{3}{*}{0.64} \\
\hline B1 & 2000 & 500 & 5.00 & 50000 & 315.5 & 261.7 & 0.52 & \\
\hline B1 & 2000 & 500 & 5.00 & 50000 & 316.6 & 256.4 & 0.53 & \\
\hline a2 & 2000 & 500 & 5.00 & 500.00 & 305.8 & 260.2 & 0.52 & \multirow{3}{*}{0.62} \\
\hline a2 & 2000 & 500 & 5.00 & 50000 & 308.4 & 2508 & 0.52 & \\
\hline a2 & 2000 & 500 & 5.00 & 500.00 & 308.1 & 2618 & 0.52 & \\
\hline 93 & 2000 & 500 & 5.00 & 50000 & 3004 & 248.6 & 0.50 & \multirow{3}{*}{0.61} \\
\hline 83 & 2000 & 5.00 & 5.00 & 50000 & 301.9 & $254:$ & 0.51 & \\
\hline 83 & 2000 & 500 & 5.00 & 50000 & 298.5 & 256.1 & 0.51 & \\
\hline
\end{tabular}

Sumber : Heil Nala Penuses 2017

4.3. Pengujian Kuat Tekan Kayu (SNI 03-68482002).

Tabel 4.13. Kayu Gamalina

\begin{tabular}{|c|c|c|c|c|c|c|c|}
\hline \multirow{2}{*}{ No. Sampel } & \multicolumn{3}{|c|}{ Dimensi Kayu } & \multirow{2}{*}{$\begin{array}{c}\text { Luas Bidang } \\
\text { Tekan (A) } \\
\left(\mathrm{mm}^{2}\right)\end{array}$} & \multirow{2}{*}{$\begin{array}{c}\begin{array}{c}\text { Beban } \\
\text { Maksimum } \\
\text { (kN) }\end{array} \\
\end{array}$} & \multirow{2}{*}{$\begin{array}{l}\text { Kuat } \\
\text { Tekan } \\
(\mathrm{MPa})\end{array}$} & \multirow{2}{*}{ 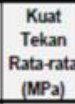 } \\
\hline & $t(m m)$ & $h(\mathrm{~mm})$ & $b(\mathrm{~mm})$ & & & & \\
\hline B1 & 200.00 & 48.00 & 50.00 & 2450.00 & 74.0 & 30.2 & \multirow{9}{*}{30.39} \\
\hline B1 & 20000 & 49.00 & 50.00 & 2450.00 & 80.0 & 32.7 & \\
\hline B1 & 200.00 & 49.00 & 50.00 & 2450.00 & 94.0 & 38.4 & \\
\hline$B 2$ & 200.00 & 48.00 & 50.00 & 2450.00 & 70.0 & 28.6 & \\
\hline$B 2$ & 200.00 & 49.00 & 50.00 & 2450.00 & 73.0 & 29.8 & \\
\hline$B 2$ & 200.00 & 49.00 & 50.00 & 2450.00 & 65.0 & 26.5 & \\
\hline B3 & 200.00 & 49.00 & 50.00 & 2450.00 & 76.0 & 31.0 & \\
\hline B3 & 20000 & 49.00 & 50.00 & 2450.00 & 63.0 & 25.7 & \\
\hline B3 & 200.00 & 49.00 & 50.00 & 2450.00 & 75.0 & 30.8 & \\
\hline
\end{tabular}

Sumber: Hasil Analisa Penulis 2017
Tabel 4.14. Kayu Kabesak

\begin{tabular}{|c|c|c|c|c|c|c|c|}
\hline \multirow{2}{*}{ No. Sampel } & \multicolumn{3}{|c|}{ Dimensi Kayu } & \multirow{2}{*}{$\begin{array}{l}\text { Luas Bidang } \\
\text { Tekan (A) } \\
\text { (mm²) }\end{array}$} & \multirow{2}{*}{$\begin{array}{c}\text { Beban } \\
\text { Maksimum } \\
(\mathrm{kN})\end{array}$} & \multirow{2}{*}{$\begin{array}{l}\text { Kuat } \\
\text { Tekan } \\
\text { (MPa) }\end{array}$} & \multirow{2}{*}{$\begin{array}{c}\text { Kuat } \\
\text { Tekan } \\
\text { Ratarata } \\
\text { (MPa) } \\
\end{array}$} \\
\hline & $\mathrm{t}(\mathbf{m m})$ & $h(\mathrm{~mm})$ & $b(\mathrm{~mm})$ & & & & \\
\hline 81 & 200.00 & 50.00 & 50.00 & 2500.00 & 102.0 & 40.8 & \multirow{9}{*}{34.00} \\
\hline B1 & 200.00 & 50.00 & 50.00 & 2500.00 & 95.0 & 38.0 & \\
\hline 81 & 200.00 & 50.00 & 50.00 & 2500.00 & 97.0 & 38.8 & \\
\hline$B 2$ & 200.00 & 50.00 & 50.00 & 2500.00 & 80.0 & 35.6 & \\
\hline$B 2$ & 200.00 & 50.00 & 50.00 & 2500.00 & 85.0 & 38.0 & \\
\hline $\mathrm{B} 2$ & 200.00 & 80.00 & 50.00 & 2500.00 & 99.0 & 38.6 & \\
\hline B3 & 200.00 & 50.00 & 50.00 & 2500.00 & 69.0 & 27.6 & \\
\hline B3 & 200.00 & 50.00 & 50.00 & 2500.00 & 50.0 & 20.0 & \\
\hline B3 & 200.00 & 50.00 & 50.00 & 2500.00 & 69.0 & 27.6 & \\
\hline
\end{tabular}

Tabel 4.15. Kayu Johar

\begin{tabular}{|c|c|c|c|c|c|c|c|}
\hline \multirow[b]{2}{*}{ No. Sampel } & \multicolumn{3}{|c|}{ Dimensi Kayu } & \multirow{2}{*}{$\begin{array}{c}\text { Luas Bidang } \\
\text { Tekan (A) } \\
\left(\mathrm{mm}^{2}\right)\end{array}$} & \multirow{2}{*}{$\begin{array}{c}\text { Beban } \\
\text { Maksimum } \\
(\mathrm{kN})\end{array}$} & \multirow{2}{*}{$\begin{array}{l}\text { Kuat } \\
\text { Tekan } \\
\text { (MPa) }\end{array}$} & \multirow{2}{*}{$\begin{array}{c}\text { Kuat } \\
\text { Tekan } \\
\text { Ratarata } \\
\text { (MPa) }\end{array}$} \\
\hline & $t(m m)$ & $h(\mathbf{m m})$ & $\mathrm{b}(\mathrm{mm})$ & & & & \\
\hline B1 & 200.00 & 50.00 & 50.00 & 2500.00 & 180.0 & 720 & \multirow{9}{*}{62.18} \\
\hline B1 & 200.00 & 50.00 & 80.00 & 2500.00 & 180.0 & 720 & \\
\hline$B 1$ & 200.00 & 50.00 & 50.00 & 2500.00 & 183.0 & 05.2 & \\
\hline B2 & 200.00 & 50.00 & 50.00 & 2500.00 & 150.0 & 02.4 & \\
\hline$B 2$ & 200.00 & 50.00 & 50.00 & 2500.00 & 159.0 & 63.6 & \\
\hline$B 2$ & 20000 & 50.00 & 50.00 & 2500.00 & 1550 & 020 & \\
\hline B3 & 200.00 & 50.00 & 50.00 & 2500.00 & 145.0 & 58.0 & \\
\hline B3 & 200.00 & 50.00 & 50.00 & 2500.00 & 129.0 & 51.6 & \\
\hline B3 & 200.00 & 50.00 & 50.00 & 2500.00 & 132.0 & 528 & \\
\hline
\end{tabular}

Sumber : Hasil Analisa Penulis 2017

Tabel 4.16. Kayu Jambu Air

\begin{tabular}{|c|c|c|c|c|c|c|c|}
\hline \multirow{2}{*}{ No. Sampel } & \multicolumn{3}{|c|}{ Dimensi Kayu } & \multirow{2}{*}{$\begin{array}{l}\text { Luas Bidang } \\
\text { Tekan (A) } \\
\left(\mathrm{mm}^{2}\right)\end{array}$} & \multirow{2}{*}{$\begin{array}{c}\begin{array}{c}\text { Beban } \\
\text { Maksimum } \\
(\mathrm{kN})\end{array} \\
\end{array}$} & \multirow{2}{*}{$\begin{array}{l}\text { Kuat } \\
\text { Tekan } \\
\text { (MPa) }\end{array}$} & \multirow{2}{*}{$\begin{array}{c}\text { Kuat } \\
\text { Tekan } \\
\text { Ratarata } \\
\text { (MPa) }\end{array}$} \\
\hline & $t(\mathbf{m m})$ & $h(\mathbf{m m})$ & $b(\mathrm{~mm})$ & & & & \\
\hline B1 & 200.00 & 50.00 & 50.00 & 2500.00 & 174.0 & 69.8 & \multirow{9}{*}{48.58} \\
\hline 81 & 200.00 & 50.00 & 50.00 & 2500.00 & 109.0 & 67.6 & \\
\hline$\overline{B 1}$ & 200.00 & 50.00 & 50.00 & 2500.00 & 100.0 & 64.0 & \\
\hline$B 2$ & 200.00 & 50.00 & 50.00 & 250000 & 140.0 & 58.0 & \\
\hline$B 2$ & 200.00 & 50.00 & 50.00 & 2500.00 & 130.0 & 520 & \\
\hline$B 2$ & 200.00 & 50.00 & 50.00 & 2500.00 & 100.0 & 40.0 & \\
\hline 83 & 200.00 & 50.00 & 50.00 & 2500.00 & 80.0 & 320 & \\
\hline B3 & 200.00 & 50.00 & 50.00 & 2500.00 & 77.0 & 30.8 & \\
\hline B3 & 200.00 & 50.00 & 50.00 & 250000 & 630 & 28.2 & \\
\hline
\end{tabular}

Tabel 4.17. Kayu Ketapang Hutan

\begin{tabular}{|c|c|c|c|c|c|c|c|}
\hline \multirow{2}{*}{ No. Sampel } & \multicolumn{3}{|c|}{ Dimensi Kayu } & \multirow{2}{*}{$\begin{array}{l}\text { Luas Bidang } \\
\text { Tekan (A) } \\
\text { (mm') }\end{array}$} & \multirow{2}{*}{$\begin{array}{c}\text { Beban } \\
\text { Maksimum } \\
\text { (kN) }\end{array}$} & \multirow{2}{*}{$\begin{array}{l}\text { Kuat } \\
\text { Tekan } \\
\text { (MPa) }\end{array}$} & \multirow{2}{*}{$\begin{array}{c}\text { Kuat } \\
\text { Tekan } \\
\text { Ratarata } \\
\text { (MPa) }\end{array}$} \\
\hline & $t(m m)$ & $h(\mathrm{~mm})$ & $\mathrm{b}(\mathrm{mm})$ & & & & \\
\hline B1 & 200.00 & 50.00 & 50.00 & 2500.00 & 90.0 & 38.4 & \multirow{9}{*}{33.07} \\
\hline 81 & 200.00 & 50.00 & 50.00 & 2500.00 & 92.0 & 36.8 & \\
\hline 81 & 200.00 & 50.00 & 50.00 & 2500.00 & 88.0 & 35.2 & \\
\hline 82 & 200.00 & 50.00 & 50.00 & 2500.00 & 80.0 & 320 & \\
\hline 82 & 200.00 & 50.00 & 50.00 & 2500.00 & 82.0 & 32.8 & \\
\hline 82 & 200.00 & 50.00 & 80.00 & 2500.00 & 70.0 & 30.4 & \\
\hline B3 & 200.00 & 50.00 & 50.00 & 2500.00 & 78.0 & 31.2 & \\
\hline B3 & 200.00 & 50.00 & 5000 & 2500.00 & 76.0 & 30.4 & \\
\hline B3 & 200.00 & 50.00 & 50.00 & 2500.00 & 76.0 & 304 & \\
\hline
\end{tabular}

Sumber : Hasil Analisa Penulis 2017 
Tabel 4.18. Kayu Mahoni

\begin{tabular}{|c|c|c|c|c|c|c|c|}
\hline \multirow{2}{*}{ No. Sampel } & \multicolumn{3}{|c|}{ Dimensi Kayu } & \multirow{2}{*}{$\begin{array}{l}\text { Luas Bidang } \\
\text { Tekan (A) } \\
\left(\mathrm{mm}^{2}\right)\end{array}$} & \multirow{2}{*}{$\begin{array}{c}\text { Beban } \\
\text { Maksimum } \\
(\mathrm{kN})\end{array}$} & \multirow{2}{*}{$\begin{array}{l}\text { Kuat } \\
\text { Tekan } \\
\text { (MPa) }\end{array}$} & \multirow{2}{*}{$\begin{array}{c}\text { Kuat } \\
\text { Tekan } \\
\text { Ratarata } \\
\text { (MPa) }\end{array}$} \\
\hline & $t(\mathrm{~mm})$ & $h(\mathrm{~mm})$ & $\mathrm{b}(\mathrm{mm})$ & & & & \\
\hline B1 & 200.00 & 50.00 & 50.00 & 2500.00 & 87.0 & 34.8 & \multirow{9}{*}{30.49} \\
\hline B1 & 200.00 & 50.00 & 50.00 & 2500.00 & 02.0 & 36.8 & \\
\hline B1 & 200.00 & 50.00 & 50.00 & 2500.00 & 77.0 & 30.8 & \\
\hline$B 2$ & 200.00 & 50.00 & 50.00 & 2500.00 & 78.0 & 31.2 & \\
\hline 82 & 200.00 & 50.00 & 50.00 & 2500.00 & 70.0 & 280 & \\
\hline B2 & 200.00 & 50.00 & 50.00 & 2500.00 & 76.0 & 30.4 & \\
\hline B3 & 200.00 & 50.00 & 50.00 & 2500.00 & 68.0 & 27.2 & \\
\hline B3 & 200.00 & 50.00 & 50.00 & 2500.00 & 68.0 & 27.2 & \\
\hline 83 & 200.00 & 50.00 & 50.00 & 2500.00 & 70.0 & 28.0 & \\
\hline
\end{tabular}

Sumber: Hasil Analisa Penulis 2017

\section{KESIMPULAN DAN SARAN}

\subsection{Kesimpulan}

Kesimpulan yang diambil dalam penelitian ini adalah Kayu Lokal di Pulau Timor ini sangat baik di gunakan pada kegiatan kontruksi karena sangat kuat baik kuat tekannya, kadar airnya rendah, maupun berat jenisnya. Adapun kuat tekan rata-rata kayu Gamalin adalah 30,39 Mpa, kayu Kabesak 34 Mpa, kayu Johar 62,18 Mpa, kayu Jambu Air 48,58 Mpa, kayu Ketapang Hutan 33, 07 Mpa, kayu Mahoni 30,49 Mpa. Kadar air kayu Gamalin adalah 18,30 $\%$, kayu Kabesak 17,73 \%, kayu Johar 18,83 \%, kayu Jambu Air 19,90 \%, kayu Ketapang Hutan $18,85 \%$, kayu Mahoni $18,73 \%$. Berat jenis kayu Gamalin adalah 0,54 kayu Kabesak 0,62, kayu Johar 0,85, kayu Jambu Air 0,67, kayu Ketapang Hutan 0,58, kayu Mahoni 0,54.

\subsection{Saran}

Saran yang di sampaikan melalui penelitian ini adalah adanya penelitian lanjutan tentang lendutan kayu sehingga dapat di ketahui berapa besar lendutan yang terjadi pada kayu-kayu lokal di Pulau Timor.

\section{DAFTAR PUSTAKA}

Anonimous, 2002. SNI Kayu Tahun 2002. DPMB, Dirjen Cipta Karya.

Bambang Suryoatmono, Struktur Kayu, Fakultas Teknik Universitas Parahyangan, Bandung.

Danasasmita, E. Kosasih, 2004. Struktur Kayu I, Fakultas Pendidikan Teknologi dan Kejuruan, UPI, Bandung.

Danasasmita, E. Kosasih, 2004. Struktur Kayu II, Fakultas Pendidikan Teknologi dan Kejuruan, UPI, Bandung.

DPMB. Cipta Karya, 1978. Peraturan Konstruksi Kayu Indonesia, DPMB, Dirjen Cipta Karya.

D. T. Gunawan, Diktat Kuliah Konstruksi Kayu, Fakultas Teknik Universitas Parahyangan, Bandung.

Felix Yap, K. H, 1965. Konstruksi Kayu, Bina Cipta, Bandung.

Frick, Heinz, 1977. Ilmu Konstruksi Kayu, Yayasan Kanisius, Yogyakarta.

Sadji, Konstruksi Kayu, Fakultas Teknik Sipil, Institut Teknologi 10 Nopember, Surabaya.

Soeryanto Basar Moelyono, 1974. Pengantar Perkayuan, Yayasan Kanisius, Yogyakarta. 